\title{
PENGELOLAAN PERIKANAN PELAGIS BESAR DENGAN PENDEKATAN EKOSISTEM DI KABUPATEN MAMUJU UTARA SULAWESI BARAT
}

\author{
Nia Istiani Wahid ${ }^{1}$ \\ Rinda Noviyanti2 \\ Etty Riani3 \\ 1Sekda Kab.Pasangkayu, Mamuju \\ 2Universitas Terbuka, Jakarta \\ 3Institut Pertanian Bogor, Bogor \\ e-mail: n1a_wahid@yahoo.co.id
}

\begin{abstract}
Fisheries management in North Mamuju Regency has not been integrated. Socio-economic interests tend to get more attention than ecosystem health of fish resources, as a target of capture. Such management conditions affect the abundance of fish resources. This can be seen by the decline in the number of catches of fishermen in the same catchment area in the last five years. This study aims to determine the conditions of fisheries management in North Mamuju Regency with an Ecosystem Approach to Fisheries Management (EAFM) and formulate recommendations for management improvement. The basis of EAFM analysis is, used 30 indicators incorporated in six domains, namely (1) Fish Resources; (2) Habitat and Ecosystems; (3) Fishing Techniques; (4) Social; (5) Economy; and (6) Institution. The results showed that the condition of the Great Pelagic fisheries management was in moderate to good conditions, the composite value range between 42-68 with an overall aggregate value of 54 , so that it was generally classified as moderate. The institutional and economic domains have good status with composite values of 68 and 65 respectively, while the other four domains are of moderate status. The recommendations are, the regulation of the number of fishing gear and use of fish aggregating device (FADs), water pollution control and water quality monitoring, improvement of supervision and law enforcement for destructive fishing gear operations, assistance with local knowledge in fisheries management, extension of asset management and business diversification assistance, application of principles the principle of the Code of Conduct Responsible Fisheries (CCRF) and the application of regulations apply.
\end{abstract}

Keywords: EAFM, Great Pelagic, North Mamuju

\section{ABSTRAK}

Pengelolaan perikanan di Kabupaten Mamuju Utara belum dilakukan secara terintegrasi. Kepentingan sosial ekonomi cenderung mendapatkan perhatian lebih dibandingkan kesehatan ekosistem sebagai wadah dari sumber daya ikan, sebagai target penangkapan. Kondisi pengelolaan yang demikian mempengaruhi kelimpahan sumber daya ikan. Hal ini terlihat dengan menurunnya jumlah hasil tangkapan nelayan pada daerah tangkapan yang sama dalam lima tahun terakhir. Penelitian ini bertujuan untuk mengetahui kondisi pengelolaan perikanan di Kabupaten Mamuju Utara dengan pendekatan ekosistem atau Ecosystem Approach to Fisheries Management (EAFM) dan menyusun rekomendasi untuk 
perbaikan pengelolaan. Dasar analisis EAFM dalam penelitian ini menggunakan 30 indikator yang tergabung dalam enam domain, yaitu: (1) Sumber Daya lkan; (2) Habitat dan Ekosistem; (3) Teknik Penangkapan Ikan; (4) Sosial; (5) Ekonomi; dan (6) Kelembagaan. Hasil penelitian menunjukkan kondisi pengelolaan perikanan Pelagis Besar berada pada kondisi sedang hingga baik, kisaran nilai komposit yang diperoleh antara 42-68 dengan nilai agregat keseluruhan 54 , sehingga secara umum tergolong dalam status sedang. Domain kelembagaan dan ekonomi memiliki status baik dengan nilai komposit masing-masing 68 dan 65 , sedangkan empat domain lainnya memiliki status sedang. Rekomendasi yang disusun meliputi pengaturan jumlah alat tangkap ikan dan penggunaan rumpon, pengendalian pencemaran perairan dan monitoring kualitas air, peningkatan pengawasan dan penegakan hukum terhadap operasi alat tangkap destruktif, pendampingan pengetahuan lokal dalam pengelolaan perikanan, penyuluhan pengelolaan asset dan pendampingan diversifikasi usaha, penerapan prinsip-prinsip Code Of Conduct Responsible Fisheries(CCRF), dan penerapan peraturan berlaku.

Kata kunci: EAFM, Pelagis Besar, Mamuju Utara

Letak geografis Kabupaten Mamuju Utara yang berbatasan langsung dengan Selat Makassar menjadikan perikanan sebagai salah satu sektor penggerak ekonomi masyarakat. Perkembangan pembangunan di Kabupaten Mamuju Utara selama 10 tahun terakhir telah meningkatkan tekanan ekonomi dan pertumbuhan penduduk. Hal tersebut berdampak pada upaya masyarakat dalam memenuhi kebutuhan hidup, salah satunya adalah aktivitas penangkapan ikan. Selama 2010-2014 terjadi peningkatan jumlah alat tangkap rata-rata sebesar 11,6\% per tahun, meskipun dua tahun setelahnya (2015-2016) mengalami penurunan namun tidak signifikan (DKP Mamuju Utara, 2016).

Peningkatan aktivitas penangkapan yang dilakukan tidak disertai dengan perhatian terhadap ekosistem sebagai wadah dari sumber daya ikan. Kondisi pengelolaan yang demikian mempengaruhi tingkat kelimpahan sumber daya ikan. Hal ini terlihat dengan menurunnya jumlah hasil tangkapan nelayan pada daerah tangkapan yang sama dalam lima tahun terakhir. Menurut Charles dalam Andrianto, dkk. (2014) pengelolaan perikanan tidak dapat dilepaskan dari tiga dimensi yang saling terkait yaitu: (1) dimensi pemanfaatan sumber daya perikanan dan ekosistemnya; (2) dimensi pemanfaatan sumber daya perikanan untuk kepentingan sosial ekonomi; dan (3) dimensi kebijakan perikanan itu sendiri. Pengelolaan yang berkelanjutan diperlukan adanya keseimbangan antar dimensi pemanfaatan Sumber Daya Ikan (SDI) tersebut. Pengelolaan perikanan Kabupaten Mamuju Utara saat ini masih parsial dan terjadi ketimpangan perhatian antar dimensi pengelolaan perikanan. Dimensi pemanfaatan SDI untuk kepentingan ekonomi lebih diperhatikan dibandingkan dengan dimensi pemanfaatan SDI. Pemerintah daerah cenderung berusaha meningkatkan hasil tangkapan tanpa disertai dengan perhatian akan kesehatan ekosistem. Dengan demikian pengelolaan perikanan di Kabupaten Mamuju Utara perlu dilakukan perbaikan. Salah satu pendekatan pengelolaan yang dapat digunakan adalah Ecosystem Approach Fisheries Management (EAFM).

Pendekatan pengelolaan perikanan dalam EAFM adalah dengan melakukan evaluasi keragaan pengelolaan perikanan yang sedang berjalan dengan menggunakan perangkat indikator yang tergabung dalam enam domain EAFM (sumber daya ikan, habitat, teknik penangkapan ikan, sosial, ekonomi, dan kelembagaan). Setelah itu ditentukan rekomendasi sebagai upaya perbaikan 
pengelolaan melalui pendekatan ekosistem (EAFM) berdasarkan hasil dari evaluasi tersebut (Andrianto, dkk., 2014). Hasil dari penilaian tersebut dapat membantu penyusun kebijakan menjadi lebih terarah karena jelas indikator mana yang memerlukan perbaikan, dipertahankan ataupun ditingkatkan serta pemberian prioritas perhatian terlebih dahulu dalam program.

EAFM secara sederhana sesungguhnya menitikberatkan pada keterkaitan antara target spesies sumber daya ikan dengan ekosistem perairan dan segenap unsur yang terkait di dalamnya (Pikitch, et. al. dalam Andrianto, dkk., 2014). Target spesies sumber daya ikan yang menjadi fokus adalah Pelagis Besar yaitu Tuna dan Cakalang. Kedua jenis ikan tersebut merupakan hasil tangkapan utama dengan alat tangkap pancing. Tujuan penelitian ini adalah: (1) Mengevaluasi kondisi terkini pengelolaan perikanan pelagis besar di Kab. Matra berdasarkan indikator EAFM dan; (2) Menyusun rekomendasi sebagai bahan masukan rencana perbaikan pengelolaan perikanan Pelagis Besar di Kabupaten Mamuju Utara.

\section{METODE PENELITIAN}

Pengambilan data penelitian dilakukan pada bulan Oktober 2017 s/d Januari 2018 di tujuh kecamatan pesisir, yaitu Kecamatan Pasangkayu, Bambalamotu, Lariang, Tikke Raya, Baras, Sarudu, dan Dapurang. Data primer penelitian dikumpulkan melalui (1) wawancara pada 34 responden terdiri atas 23 nelayan, dua pegawai Dinas Kelautan dan Perikanan Kabupaten Mamuju Utara, dua Pengawas perikanan Satker Kabupaten Mamuju Utara, dan tujuh Kepala dan atau Lurah desa; (2) Pengukuran langsung, dilakukan pada indikator juwana menggunakan panjang total (Andrianto, dkk., 2014), status mangrove dengan metode transek (Odum, 1993; Bengen, 2002; Bengen, 1999), lamun dengan metode sea grass watch (McKenzie, 2003.; McKenzie, 2008; McKenzie, Campbell \& Roder, 2003) dan terumbu karang dengan metode Rapid Reef Assesment (English, Wilkinson \& Baker, 1994; Sukmara, Siahainenia \& Rotinsulu, 2002; Brown, 1986).

Data sekunder dikumpulkan melalui studi kepustakaan, meliputi dokumen laporan dan data statistik perikanan Kabupaten Mamuju Utara, laporan hasil patrol pengawas perikanan satker Mamuju Utara, laporan penyusunan database mangrove Kabupaten Mamuju Utara oleh Badan Lingkungan Hidup Provinsi Sulawesi Barat, laporan hasil penelitian baik dari berbagai lembaga riset, perguruan tinggi, perusahaan swasta, maupun LSM.

Analisis data dilakukan dengan:

Catch Per Unit Effort (CPUE) (Wahyudi dalam Listiani, Wijayanto \& Jayanto, 2017)

$$
C P U E=\frac{\mathrm{Cs}}{\mathrm{Es}} \quad, P I=\frac{\mathrm{CPUEi}}{\mathrm{CPUEs}}, \text { Effort }=\mathrm{FPI}{ }^{*} \mathrm{Es}
$$

Ket. Cs = hasil tangkapan (catch) per tahun alat tangkap (ton)

Es = upaya penangkapan (effort) per tahun alat tangkap (unit)

$\mathrm{FPI} \quad=$ indeks kuasa penangkapan alat tangkap

CPUEi = hasil tangkapan per upaya penangkapan tahunan alat tangkap lain (ton/unit)

CPUEs = hasil tangkapan per upaya tahunan alat tangkap standar (ton/unit)

Effort = upaya penangkapan alat tangkap setelah di standarisasi

Frekuensi Panjang Ikan (Effendi dalam Adianto, dkk., 2014)

a. Menentukkan nilai maksimum dan minimum dari seluruh data panjang ikan.

b. Menetapkan jumlah kelas dan interval kelas dengan melihat hasil pengamatan frekuensi pada setiap selang kelas panjang ikan. 
c. Menentukan nilai batas bawah kelas bagi selang kelas yang pertama dan kemudian batas atas kelas.

d. Mendaftarkan pada semua batas kelas untuk setiap selang kelas.

e. Menentukkan nilai tengah kelas bagi masing-masing kelas dengan merata-ratakan batas kelas.

f. Menentukkan frekuensi bagi masing-masing kelas.

Mangrove (Bengen, 2002; Bengen, 1999)

a Kerapatan Jenis $(\mathrm{Di})$

$$
\mathrm{Di}=\frac{n i}{A},
$$

Ket. $\mathrm{Di}=$ Kerapatan jenis $\left(\mathrm{ind} / \mathrm{m}^{2}\right)$

$\mathrm{Ni}=$ Jumlah total tegakan jenis $\mathrm{i}$

$A=$ Luas total area pengambilan contoh

b. Kerapatan Relatif Jenis $(R D i)$

$$
\mathrm{RDi}=\frac{n i}{\sum n} \times 100 \%
$$

Ket. $\mathrm{RDi}=$ Kerapatan relatif penting $(\%)$

$$
\begin{aligned}
& n \mathrm{ni}=\text { Jumlah total tegakan jenis } \mathrm{i} \\
& \mathrm{n}=\text { Jumlah total tegakan seluruh jenis }
\end{aligned}
$$

c. Frekuensi Jenis (Fi)

$$
\mathrm{Fi}=\frac{p i}{\sum p}
$$

Ket. $\mathrm{Fi}=$ Frekuensi jenis

$\mathrm{pi}=$ Jumlah petak contoh ditemukan jenis $\mathrm{i}$

$\mathrm{p}=$ Jumlah total petak contoh yang diamati

d. Frekuensi Relatif Jenis (RFi)

$$
\mathrm{RFi}=\frac{F i}{\sum F} \times 100 \%
$$

Ket. $\mathrm{RFi}=$ Frekuensi relatif jenis

$$
\mathrm{Fi}=\text { Frekuensi jenis }
$$

e. Penutupan Jenis $(\mathrm{Ci})$

$$
\mathrm{Ci}=\frac{\sum B A}{A}, \mathrm{BA}=\frac{\pi D B H^{2}}{4}, \mathrm{DBH}=\frac{C B H}{\pi}
$$

Ket. $\mathrm{Ci}=$ Penutupan Jenis, BA (dalam $\mathrm{cm}^{2}$ )

$\mathrm{DBH}=$ Diameter pohon jenis $\mathrm{i}(\mathrm{cm})$

$\pi=$ Konstanta $(3,1416)$

$\mathrm{CBH}=$ Lingkaran pohon setinggi dada 
f. Penutupan Relatif Jenis (RCi)

$$
\mathrm{RCi}=\frac{C i}{\sum C} \times 100 \%
$$

Ket. $\mathrm{RCi}=$ Penutupan relatif jenis

$\mathrm{Ci}=$ Luas area penutupan jenis $\mathrm{i}$

$C=$ Luas total area untuk seluruh jenis

g. Indeks Nilai Penting (INP)

$$
\text { INP = RDi + RFi + RCi }
$$

Lamun (McKenzie, 2003; McKenzie, 2008; McKenzie, Campbell \& Roder, 2003)

a. Penutupan lamun dalam satu kuadrat $(\%)=$ Jumlah nilai penutupan lamun (4 kotak) dibagi 4

b. Rata-rata penutupan lamun per stasiun $(\%)=$ Jumlah penutupan lamun seluruh transek dibagi jumlah kuadrat seluruh transek.

c. Menghitung penutupan lamun per jenis pada satu stasiun/rata-rata nilai dominasi lamun $(\%)=$ jumlah nilai penutupan setiap jenis lamun pada seluruh kuadrat dibagi jumlah kuadrat seluruh transek.

d. Menghitung rata-rata penutupan lamun per lokasi $(\%)=$ jumlah nilai rat-rata penutupan lamun seluruh stasiun dalam satu lokasi dibagi jumlah stasiun dalam satu lokasi.

Terumbukarang (English, Wilkinson \& Baker, 1994)

Persen penutupan (\%) diperoleh dari hasil bagi antara Panjang total kelompok karang dengan Panjang transek dikalikan 100.

Penilaian Indikator EAFM (Andrianto, dkk., 2014)

1. Mengkaji keragaan setiap indikator/atribut yang diuji berdasarkan perolehan data terbaik dengan menggunakan kriteria dan batasan nilai (reference point) yang telah ditentukan dalam Modul EAFM.

2. Memberikan nilai skor untuk setiap atribut yang diuji menggunakan skort Likert (berbasis ordinal $1,2,3)$ berdasarkan hasil yang diperoleh dari setiap atribut pada masing-masing domain dengan membandingkan pada reference point. Pemberian skor ini merupakan suatu cara agar perbedaan satuan dari nilai yang dimiliki setiap atribut berada dalam satu analisa yang terintegrasi. Dengan teknik scoring ini maka semua indikator yang ada dalam penilaian terlihat memberikan konstribusi yang seimbang. Proses pemberian skor ini menunjukkan baik buruknya suatu indikator, dimana nilai 1 merupakan skor terendah yang berarti indikator memiliki kondisi yang buruk, nilai 2 berarti sedang dan nilai 3 merupakan skor tertinggi yang berarti kondisi yang baik.

3. Menentukkan nilai indeks setiap atribut dengan rumus:

\section{Cat $-i=$ Sai ${ }^{*} i$}

Ket. Cat $-\mathrm{i}=$ Nilai total EAFM dari satu atribut dalam domain

Sai $=$ Skor atribut ke-i

4. Menentukkan nilai setiap domain yang berasal dari total nilai seluruh atribut pada masingmasing domain dengan rumus:

$\Sigma$ Cat $-i=$ Sai * Wi

Ket. $W i=$ Bobot atribut ke-i (bobot sudah ditetapkan) 
5. Menganalisa nilai dari masing-masing domain dengan menggunakan analisis komposit sederhana berbasis aritmatik. Indeks komposit ini merupakan nilai konversi nilai total dari setiap domain EAFM. Proses ini diperlukan agar diperoleh batasan yang baku dari nilai EAFM dengan skala 1-100 sehingga memudahkan dalam memberikan kategori dari setiap domain EAFM. Nilai konversi skala setiap domain ditentukan dengan rumus:

$$
\mathrm{Nk}-\mathrm{i}=\frac{C a t-i}{C a t-i \max } * 100
$$

Ket. Cat- $i=$ Nilai total EAFM dari satu atribut dalam domain

Cat-imax = Nilai maksimum dari satu atribut dalam domain yang diperoleh saat semua atribut memiliki skor 3

6. Menentukan nilai skala konversi kawasan dengan cara merata-ratakan seluruh domain yang dikaji

$$
\mathrm{Nk}-\mathrm{i}=\left(\frac{C a t-i}{C a t-i \max }\right) / N * 100
$$

Ket. $\mathrm{N}=$ jumlah domain dalam EAFM

7. Hasil dari nilai konversi skala ditampilkan dalam bentuk model bendera (flag model) dengan 5 kriteria berdasarkan skala atau batasan nilai yang diperoleh. Skala setiap domain menggambarkan status pengelolaan suatu wilayah pada masing-masing domain, sedangkan skala kawasan menggambarkan status pegelolaan perikanan di kawasan tersebut secara keseluruhan.

Tabel 1. Penggolongan Indeks Komposit dan Visualisasi Model Bendera

\begin{tabular}{ccll}
\hline \multicolumn{2}{c}{ Rentang nilai (\%) } & \multirow{2}{*}{ Model bendera } & Deskripsi \\
Rendah & tinggi & & penerapan EAFM \\
\hline 1 & 20 & Merah & buruk \\
21 & 40 & Putih & kurang \\
41 & 60 & Kuning & sedang \\
61 & 80 & Hijau muda & baik \\
81 & 100 & Hijau tua & sekali \\
\hline
\end{tabular}

\section{HASIL DAN PEMBAHASAN}

\section{Domain Sumber Daya Ikan}

Domain sumber daya ikan terdiri dari lima indikator yaitu trend CPUE, trend ukuran ikan, proporsi ikan juwana, spesies Endangered, Threatened and Protected (ETP), dan range collapse sumber daya ikan. Nilai komposit indikator pada domain sumber daya ikan sebesar 170 , analisis komposit pada domain sumber daya ikan disajikan pada Tabel 2.

Hasil penelitian menunjukkan trend CPUE perikanan pelagis besar di Mamuju Utara mengalami penurunan rerata $15 \%$ per tahun dengan bertambahnya upaya penangkapan. Trend CPUE yang menurun memberikan indikasi bahwa pemanfaatan sumber daya ikan tersebut sudah tinggi atau overfishing (Nugraha, Bachrulla \& Yuniarti, 2012). Hasil wawancara menunjukkan bahwa trend ukuran ikan pelagis besar yang ditangkap nelayan Mamuju Utara tidak mengalami perubahan selama 5-10 tahun terakhir. Ukuran ikan selama lima tahun yang tidak berubah mengindikasikan ikan 
memiliki cukup waktu untuk dewasa sebelum tertangkap dan memiliki ancaman yang kecil terhadap keberlanjutan untuk sumber daya ikan tersebut (Abdullah, Sugeng, Daneil \& Fedi, 2011).

Proporsi ikan juwana pelagis besar yang ditangkap nelayan Mamuju Utara termasuk dalam kategori banyak (30-60\%) karena tidak sepanjang tahun ukuran ikan pelagis besar yang ditangkap termasuk dalam ukuran layak tangkap. Hal tersebut disebabkan hasil pengukuran menunjukkan hanya ikan tongkol yang berada dalam ukuran layak tangkap sedangkan madidihang dan cakalang tidak, namun berdasarkan wawancara hanya madidihang dengan alat tangkap pancing dan purse seine yang berada dalam ukuran layak tangkap. Perbedaan ukuran tersebut diduga diakibatkan waktu penelitian berada dalam musim barat dimana menurut Alamsyah, Musbir \& Amir (2014) pada musim barat struktur ukuran ikan berukuran lebih kecil dibandingkan tiga musim lainnya yang disebabkan karena aktivitas penangkapan ikan hanya dilakukan di daerah pantai dengan daerah tangkapan yang terbatas. Range collapase adalah suatu fenomena yang umum terjadi ketika stok ikan mengalami overfishing dengan indikasi semakin sulitnya mencari daerah penangkapan (Andrianto, dkk., 2014).

Berdasarkan hasil wawancara daerah tangkapan saat ini menjadi semakin sulit dan jauh, bahkan beberapa hingga sampai wilayah Berau (Kalimantan) dan Lombok. Hasil tangkapan juga semakin berkurang dengan jarak yang sama menuju daerah penangkapan. Kondisi ini menunjukkan terjadi penyusutan secara spasial dari biomassa stok ikan pelagis besar sebagai target penangkapan nelayan Mamuju Utara yang merupakan dampak adanya peningkatan tekanan penangkapan ikan (Andrianto, dkk., 2014).

Tabel 2. Analisis Komposit Domain Sumber Daya Ikan

\begin{tabular}{lcrr}
\hline Indikator & Skor & Bobot & Nilai \\
\hline CPUE Baku & 2 & 40 & 80 \\
Tren ukuran ikan & 2 & 20 & 40 \\
Proporsi ikan yuwana (juvenile) yang ditangkap & 2 & 15 & 30 \\
Komposis ispesies hasil tangkapan & 0 & 10 & 0 \\
"Range Collapse" sumber daya ikan & 1 & 10 & 10 \\
Spesies ETP & 2 & 5 & 10 \\
\hline Total & & & $\mathbf{1 7 0}$ \\
\hline
\end{tabular}

Sumber: Data survei (2017)

\section{Domain Habitat}

Domain habitat terdiri atas enam indikator, yaitu kualitas perairan, status lamun, status mangrove, status terumbukarang, habitat unik/khusus, dan perubahan iklim terhadap kondisi perairan dan habitat. Nilai komposit indikator pada domain habitat dan ekosistem sebesar 140, analisis komposit pada domain habitat dan ekositem disajikan pada Tabel 3.

Kab. Mamuju Utara memiliki kualitas perairan yang buruk karena dari keberadaan limbah berada dalam kondisi tercemar sedang dan tingkat kekeruhan yang melebihi dari20 $\mathrm{mg} / \mathrm{m}^{3}$ serta ketiadaan data kandungan klorofil a. Kondisi tersebut diperoleh dari lokasi yang terbatas sehingga pengukuran lebih lanjut diperlakukan sehingga dapat member gambaran yang lebih akurat. Status padang lamun Kab. Mamuju Utara masih tergolong sedang dengan rata-rata tutupan per stasiun 2949\% dan keanekaragaman sedang dengan jenis lamun yang dimiliki antara 3-5 jenis. 
Hasil analisis memperlihatkan terjadi penurunan luasan padang lamun dari 14,4-26,4 rumpun $/ \mathrm{m}^{2}$ pada tahun 2011 menjadi 0,1-0,3 rumpun $/ \mathrm{m}^{2}$ tahun 2017. Hilangnya lamun secara luas yang telah terjadi di berbagai tempat belahan dunia merupakan akibat langsung dari aktivitas manusia (Kiswara dalam Minerva,Firda \& Agung, 2014). Aktivitas manusia di Mamuju Utara yang diduga sebagai penyebab berkurangnya luasan lamun diantaranya penangkapan ikan secara destruktif (menggunakan bom ikan dan racun ikan), aktivitas beberapa industri dan perluasan areal tambak serta aktivitas rumahtangga.

Berdasarkan hasil survei mangrove diperoleh di stasiun 1 (Kec. Tikke Raya) jenis mangrove yang ditemukan adalah Rhyzopora Stylosa dan Rhyzopora mucronate dengan kerapatan pohon sebesar 3.300 pohon/Ha, dengan tutupan masing-masing jenis $57,24 \%$ dan $42,76 \%$, pada stasiun 2 (Kec. Lariang) jenis mangrove yang ditemukansama pada stasiun 1, dengan kerapatan 3.100 pohon/Ha dan tutupan 42,60\% dan 57,40\%. Pada stasiun 3 (Kec. Baras) jenis mangrove yang ditemukan adalah Rhyzopora Stylosa dan Rhyzoporaapiculata dengan kerapatan pohon sebesar 3.200 pohon/Ha, dengan tutupan masing-masing jenis $41,11 \%$ dan $58,89 \%$, pada Kec. Sarudu jenis mangrove yang ditemukan adalah Rhyzopora Stylosa, Avicenia marina, dan Rhyzopora mucronate dengan kerapatan pohon sebesar 3.700 pohon/Ha, dengan tutupan masing-masing jenis $25,60 \%$, $29,33 \%$, dan 45,07\%, jenis mangrove paling banyak ditemukan di stasiun 4 (Kecamatan Dapurang) yaitu Rhyzopora Stylosa, Avicenia marina, Rhyzoporaapiculate, dan Rhyzopora mucronate dengan kerapatan pohon sebesar 3.400 pohon/ $\mathrm{Ha}$, dengan tutupan masing-masing jenis 19,43\%, 17,17\%, $38,07 \%$, dan $25,33 \%$.

Dengan demikian status mangrove di Mamuju Utara berada pada kondisi sedang dimana kerapatan di setiap stasiun $>3.000$ pohon/Ha termasuk dalam kategori kerapatan tinggi, untuk persentase tutupan mendapatkan nilai rata-rata tutupan sebesar $38,46 \%$ termasuk dalam kategori rendah. Data tahun 2005 luas hutan mangrove di Kabupaten Mamuju Utara adalah 4.449,2 Ha kemudian pada tahun 2015 mengalami kerusakan sehingga luasan hutan mangrove berkurang menjadi 2.340,27 Ha (Badan Lingkungan Hidup Pemerintah Provinsi Sulawesi Barat, 2015). Penurunan luasan tersebut dilaporkan akibat adanya tekanan ekonomi dan pertumbuhan penduduk, hutan mangrove dikonversi menjadi pemukiman dan pemanfaatan ekonomi yaitu perluasan tambak. Setyawan \& Winarno (2006) menyebutkan bahwa tekanan yang tidak terbaharukan pada sumber daya mangrove disebabkan oleh meningkatnya jumlah penduduk. Meskipun dari kerapatan kondisi mangrove di Kabupaten Mamuju Utara masih tergolong tinggi namun apabila tidak terdapat tindakan pengelolaan yang baik dari pemerintah daerah maka dapat diprediksi penurunan luasan hutan mangrove akan terus terjadi setiap tahun dan hal tersebut dapat mengancam kelestarian ekosistem pesisir dan sumber daya ikan.

Tabel 3. Analisis Komposit Domain Habitat

\begin{tabular}{lccc}
\hline Indikator & Skor & Bobot & Nilai \\
\hline Kualitas perairan & 1 & 25 & 25 \\
Status ekosistim lamun & 2 & 15 & 30 \\
Status ekosistim mangrove & 2 & 15 & 30 \\
Status ekosistim terumbu karang & 2 & 15 & 30 \\
Habitat unik/khusus & 1 & 20 & 20 \\
Perubahan iklim terhadap kondisi perairan dan habitat & 1 & 5 & 5 \\
\hline Total & & & 140 \\
\hline Sumber: Data survei (2017) & & &
\end{tabular}


Kondisi terumbu karang Mamuju Utara berada dalam status sedang dengan agregat \% tutupan karang hidup sebesar 40\%. Apabila dibandingkan tutupan karang tahun 2011 (62,6\%) menunjukkan kondisi terumbu karang di pesisir Mamuju Utara mengalami penurunan. Penyebab penurunan tersebut akibat masih maraknya penangkapan ikan dengan cara destruktif, baik itu dengan bom maupun dengan racun.

Kondisi habitat unik/khusus mendapatkan nilai buruk karena informasi pengetahuan akan habitat unik/khusus yang dibutuhkan tersebut belum dimiliki oleh Kabupaten Mamuju Utara baik melalui pendataan maupun kajian tertentu, berdasarkan wawancara juga tidak diperoleh informasi tersebut secara detail dikarenakan ketidaktahuan responden.

Perubahan iklim terhadap kondisi perairan dan habitat juga mendapatkan nilai buruk karena belum terdapat kajian dan strategi persentase coral bleaching saat ini belum diketahui.

\section{Domain Penangkapan Ikan}

Domain teknik penangkapan ikan terdiri dari enam indikator yaitu penangkapan ikan destruktif, modifikasi alat dan alat bantu penangkapan ikan, kapasitas perikanan dan upaya penangkapan, selektivitas penangkapan, kesesuaian fungsi dan ukuran kapal penangkapan ikan dengan dokumen legal dan sertifikasi awak kapal perikanan sesuai dengan peraturan. Nilai komposit indikator pada domain teknik penangkapan ikan sebesar 135, analisis komposit pada domain teknik penangkapan ikan disajikan pada Tabel 4.

Jumlah penangkapan ikan secara destruktif selama tahun 2016 sebanyak 17 pelanggaran berupa penggunaan potas dan bom (Laporan pengawas perikanan Satker Mamuju Utara, 2016). Menurut lkawati, dkk. dalam Latuconsina (2010) akibat penyemprotan potassium cyanide menyebabkan hewan karang mengalami stres dan mati, sedangkan pada penggunaan bom dengan berat $0,5 \mathrm{~kg}$ dapat menghancurkan karang secara total pada radius tiga meter. Sekitar $20 \%$ ikan hancur karena berada di titik ledakan sehingga terbuang sia-sia, sekitar 40\% mengapung dan 40\% sisanya tenggelam, tidak hanya itu larva ikan pun ikut hancur.

Modifikasi alat penangkapan dan alat bantu penangkapan dalam penelitian ini didefinisikan sebagai penggunaan alat tangkap dan alat bantu yang tidak sesuai dengan peraturan yang dapat menimbulkan dampak negatif terhadap sumber daya ikan (Andrianto, dkk, 2014). Pemilik rumpon di Kabupaten Mamuju Utara tidak semuanya memiliki Surat ljin Pemasangan Rumpon (SIPR) dan jarak pemasangan antar rumpon di bawah 10 mil dimana di dalam Permen KP no.26 Tahun 2014 pasal 12 ayat $1 \mathrm{~d}$. disebutkan bahwa "jarak pemasangan antara rumpon yang satu dengan rumpon lain tidak kurang dari 10 (sepuluh) mil laut". Lcmadidihang hasil tangkapan dengan penggunaan rumpon yang berada di bawah Lm. WCPFC dalam Mallawa, Amir \& Zainuddin (2014) menyatakan bahwa penggunaan alat bantu rumpon dalam penangkapan jenis ikan tuna/cakalang di perairan Pasifik dapat meningkatkan jumlah ikan muda dibandingkan dengan penangkapan melalui pemburuan gerombolan ikan.

Kapal purse seine memiliki kesesusain fungsi dan ukuran kapal penangkapan ikan dengan dokumen legal namun tidak demikian dengan kapal pancing. Kondisi tersebut sesuai pada pertimbangan bahwa kapal yang memiliki dokumen kesesuaian ukuran kapal adalah kapal di atas 5 GT (Bessy \& Aryogagautama, 2012) dan kewajiban kapal < 10 GT hanya melakukan registrasi (Budiarto, 2015), sedangkan kapal nelayan pelagis besar di Kabupaten Mamuju Utara mayoritas kapal di bawah 5GT. 
Pendekatan indikator ini dengan mengukur kepemilikan sertifikat ATKAPIN dan ANKAPIN oleh awak kapal perikanan melalui survei. Hasil survey menunjukkan bahwa belum terdapat awak kapal pelagis besar yang memiliki sertifikat ANKAPIN dan ATKAPIN, sekalipun nelayan purse seine.

Tabel 4. Analisis Komposit Domain Teknik Penangkapan Ikan

\begin{tabular}{lccc}
\hline Indikator & Skor & Bobot & Nilai \\
\hline Penangkapan ikan yang bersifat destruktif & 1 & 30 & 30 \\
Modifikasi alat penangkapan ikan dan alat bantu penangkapan & 2 & 25 & 50 \\
Kapasitas Perikanan dan Upaya Penangkapan (Fishing & 0 & 15 & 0 \\
Capacity and Effort) & & & \\
Selektivitas penangkapan & 2 & 15 & 30 \\
Kesesuaian fungsi dan ukuran kapal penangkapan ikan dengan & 2 & 10 & 20 \\
dokumen legal & 1 & 5 & 5 \\
Sertifikasi awak kapal perikanan sesuai dengan peraturan & 1 & & 135 \\
\hline Total & & &
\end{tabular}

\section{Domain Sosial}

Domain sosial terdiri dari tiga indikator yaitu indikator partisipasi pemangku kepentingan, konflik perikanan, dan pemanfaatan pengetahuan lokal. Nilai komposit indikator pada domain sosial sebesar 135, analisis komposit pada domain sosial disajikan pada Tabel 5.

Hasil wawancara menunjukkan bahwa partisipasi pemangku kepentingan dalam kegiatan pengelolaan perikanan tergolong masih rendah yaitu 39,3\% (<50\%). Pada tahun 2017 kegiatan pengelolaan perikanan masih terbatas pada empat kegiatan yaitu pengawasan di laut, penegakan hukum, temu teknis dan musrembang, keempat kegiatan tersebut hanya dihadiri oleh beberapa pemangku kepentingan.

Konflik perikanan dalam pemanfaatan perikanan pelagis besar di Kab. Mamuju Utara jarang terjadi. Hanya $8,3 \%$ responden yang menjawab pernah terjadi konflik, yaitu konflik antar nelayan lokal dan diselesaikan dengan peraturan yang adil.

Nelayan Kabupaten Mamuju Utara belum memiliki pengetahuan lokal dalam pemanfaatan sumber daya pelagis besar, namun hasil identifikasi dijumpai satu aturan adat tentang pelarangan penangkapan ikan duyung yang berkembang di Kabupaten Mamuju Utara. Aturan tersebut sudah turun-temurun diikuti, terdapat mitos yang dipercayai nelayan bahwa ikan duyung merupakan penolong dan apabila kita melukai maka akan mendapat kesialan.

Tabel 5. Analisis Komposit Domain Sosial

\begin{tabular}{lcccc}
\hline Indikator & Skor & Bobot & Ranking & Nilai \\
\hline Partisipasi pemangku kepentingan & 1 & 40 & 1 & 40 \\
Konflik perikanan & 2 & 35 & 2 & 70 \\
Pemanfaatan pengetahuan lokal dalam pengelolaan & 1 & 25 & 3 & 25 \\
sumber daya ikan & & & & \\
\hline Total & & & & $\mathbf{1 3 5}$
\end{tabular}

Total 135

Sumber: Data survei (2017) 


\section{Domain Ekonomi}

Domain ekonomi terdiri dari tiga indikator, yaitu kepemilikan asset, pendapatan rumahtangga nelayan, dan rasio tabungan. Nilai komposit indikator pada domain ekonomi sebesar 195, analisis komposit pada domain ekonomi disajikan pada Tabel 6 .

Berdasarkan hasil wawancara rata-rata nilai pendapatan rumahtangga nelayan pelagis besar di Kabupaten Mamuju Utara adalah Rp. 1.723 .000 per bulan, di bawah UMR Mamuju Utara (Rp. 2.563.039). Lebih dari 75\% pendapatan berasal dari perikanan serta dihasilkan oleh kepala rumahtangga. Kondisi tersebut menunjukkan rumahtangga nelayan pelagis besar di Kabupaten Mamuju Utara memiliki ketergantungan yang tinggi terhadap sumber daya perikanan dan kepala rumahtangga (Andrianto, dkk., 2014). Dengan demikian diperlukan pencarian sumber mata pencaharian alternatif sebagai strategi pengembangan kesejahteraan nelayan pelagis besar di Kabupaten Mamuju Utara.

Hasil pengukuran rasio tabungan memiliki hasil yang positif, yaitu sebesar $32,4 \%$ artinya nelayan pelagis besar di Mamuju Utara memiliki potensi dalam menyimpan kelebihan pendapatannya, tingkat kesejahteraan nelayan juga tergolong baik karena nilai SR $(32,4 \%)$ lebih besar dari tingkat suku bunga Bank Indonesia Tahun 2017 (4,75\%).

Nelayan pelagis besar Kabupaten Mamuju Utara meskipun memiliki potensi menabung dan dikatakan memiliki tingkat kesejahteraan yang baik namun kondisi tersebut masih menempatkan nelayan pelagis besar Kabupaten Mamuju Utara dalam kemiskinan. Dalam kasus ini dikarenakan selain nilai rata-rata pendapatan di bawah UMR juga karena rata-rata pendapatan yang lebih besar dari rata-rata pengeluaran tidak terjadi sepanjang tahun. Kondisi tersebut terjadi umumnya ketika musim puncak dan ketika musim paceklik tiba pendapatan dapat lebih kecil dari pengeluaran hingga tidak terdapat pendapatan sama sekali, situasi selanjutnya yang terjadi adalah berhutang. Oleh sebab itu potensi menabung yang ada harus terus digalakkan agar menjadi budaya dalam kehidupan nelayan pelagis besar Kabupaten Mamuju Utara.

Kepemilikan aset nelayan Mamuju Utara cenderung tetap, hal tersebut menunjukkan nelayan pelagis besar di Mamuju Utara cenderung belum memiliki kemampuan untuk menambah pendapatan.

Tabel 6. Analisis Komposit Domain Ekonomi

\begin{tabular}{lcccc}
\hline Indikator & Skor & Bobot & Ranking & Nilai \\
\hline Kepemilikan Aset & 2 & 45 & 1 & 90 \\
Pendapatan rumah tangga perikanan (RTP) & 1 & 30 & 2 & 30 \\
Rasio Tabungan (Saving ratio) & 3 & 25 & 3 & 75 \\
\hline Total & & & & 195 \\
\hline
\end{tabular}

Sumber: Data survei (2017)

\section{Domain Kelembagaan}

Domain kelembagaan terdiri dari enam indikator. Nilai komposit indikator pada domain kelembagaan sebesar 204,4. (Tabel 7).

Berdasarkan hasil wawancara menunjukkan kepatuhan pemangku kepentingan masih rendah karena pelanggaran pengelolaan perikanan terhadap aturan formal terjadi lebihdari lima kali, kepatuhan aturan informal dalam bentuk kesepakatan bersama di Kecamatan Pasangkayu dan Dapurang memiliki kesamaan dengan aturan formal yang ada yaitu pelarangan penggunaan bius ikan dalam kegiatan menangkap ikan. 
Tabel 7. Analisis Komposit Domain Kelembagaan

\begin{tabular}{lccc}
\hline Indikator & Skor & Bobot & Nilai \\
\hline Kepatuhan terhadap prinsip-prinsip perikanan yang & 1 & 25 & 25 \\
bertanggungjawab & & & \\
Kelengkapan aturan main dalam pengelolaan perikanan & 2,4 & 26 & 62,4 \\
Mekanisme pengambilan keputusan & 3 & 18 & 54 \\
Rencana pengelolaan perikanan & 1 & 15 & 15 \\
Tingkat sinergisitas kebijakan dan kelembagaan & 3 & 11 & 33 \\
pengelolaan perikanan & & & \\
Kapasitas pemangku kepentingan & 3 & 5 & 15 \\
\hline Total & & & $\mathbf{2 0 4 , 4}$ \\
\hline Sumber: Data survei (2017) & & &
\end{tabular}

Kelengkapan aturan main pengelolaan perikanan berada dalam kategori sedang. Regulasi daerah belum tersedia, masih mengacu pada regulasi pemerintah pusat atau peraturan nasional namun petugas dan peralatan. Petugas, peralatan dan tindakan serta adanya teguran dan hukuman sudah ada namun penegakan belum efektif karena masih terdapat laporan pelanggaran yang tidak mampu terjangkau khususnya di perbatasan dan hal tersebut dikarenakan kapal pengawas perikanan yang dimiliki belum memadai yaitu rubber boat atau kapal karet.

Identifikasi keputusan terkait pengelolaan perikanan di Mamuju Utara berupa ijin usaha perikanan dan operasional penangkapan serta pelanggaran kegiatan perikanan, keputusan tersebut berasal dari pemerintah pusat yang diadopsi oleh pemerintah daerah. Praktek dari keputusan tersebut melibatkan peran antar Lembaga dan berjalan saling melengkapi.

Kabupaten Mamuju Utara belum memiliki Rencana Pengelolaan Perikanan (RPP) secara khusus. Berbagai kondisi yang terjadi di Indonesia membuktikan bahwa tanpa adanya RPP memiliki dampak yang kuat terhadap ancaman semakin menipisnya potensi sumber daya ikan di beberapa daerah (Abrahamsz dan Ayal, 2015).

Berdasarkan wawancara tidak terdapat konflik kepentingan dan benturan kebijakan antarlembaga terkait, baik dalam pemanfaatan laut maupun perijinan usaha perikanan serta pelanggaran kegiatan perikanan. Kajian dokumen kebijakan masih mengadopsi peraturan pusat atau nasional, kebijakan di tingkat daerah perlu didorong untuk menjawab permasalahan yang bersifat lokal.

Terdapat peningkatan kapasitas berupa pelatihan teknis, dan semua hasil pelatihan tersebut digunakan dalam pelaksanaan tugas yang dilakukan.

\section{Penilaian Agregat}

Hasil evaluasi terhadap seluruh domain EAFM berdasarkan hasil perhitungan diperoleh kisaran nilai 42-68, dengan nilai agregat keseluruhan adalah 54. Indikasi status pengelolaan perikanan pelagis besar di Kabupaten Mamuju Utara tergolong dalam kategori sedang sampai baik. Domain kelembagaan dan domain ekonomi memiliki kontribusi domain terbaik sedangkan empat domain lainnya memiliki kontribusi sedang. Secara keseluruhan penerapan EAFM pelagis besar di Mamuju Utara tergolong dalam status sedang. Hasil perhitungan agregat selengkapnya disajikan pada Tabel 8. 
Tabel. 8. Hasil Nilai Agregat setiap Domain Indikator EAFM Perikanan Pelagis Besar di Kabupaten Mamuju Utara

\begin{tabular}{lcl}
\hline \multicolumn{1}{c}{ Domain } & Nilai Komposit & Deskripsi \\
\hline Sumber daya ikan & 57 & Sedang \\
Habitat \& ekosistem & 42 & Sedang \\
Teknik penangkapan ikan & 45 & Sedang \\
Sosial & 45 & Sedang \\
Ekonomi & 65 & Baik \\
Kelembagaan & 68 & Baik \\
\hline Aggregat & $\mathbf{5 4}$ & Sedang \\
\hline
\end{tabular}

Rekomendasi yang disusun berdasarkan hasil penilaian indikator EAFM tersebut diperlukan dalam rangka memperbaiki kondisi yang masih kurang atau sedang. Untuk domain sumber daya ikan ada beberapa rekomendasi, yaitu: pengaturan jumlah alat penangkapan ikan pelagis besar yang beroperasi yaitu, pengaturan ukuran minimal ikan pelagis besar yang boleh ditangkap, pengaturan jumlah dan pemasangan rumpon, sosialisasi tentang juwana kepada nelayan, peningkatan kesadaran dan sosialisasi terhadap nelayan tentang ETP.

Rekomendasi untuk domain habitat adalah pengendalian pencemaran perairan dan monitoring kualitas air, penetapan kawasan konservasi (Mangrove, Lamun, dan Karang), koordinasi lintas sektoral berdasarkan penyebab sedimentasi, replanting mangrove, pengendalian terhadap penggunaan alat penangkapan destruktif, pendekatan fisheries refugia, kajian tentang spawning ground, nursery ground, feeding ground dan upwelling, kajian tentang dampak perubahan iklim terhadap kondisi perairan dan habitat. Untuk domain teknik penangkapan ikan, rekomendasinya antara lain peningkatan pengawasan dan penegakan hukum terhadap operasi alat tangkap destruktif, pengaturan perijinan pemasangan rumpon, pengaturan jarak dan jumlah pemasangan rumpon, peningkatan penegakan hukum terhadap penggunaan purse seine dengan ukuran mata jaring 1 inch, pendataan dan pemeriksaan kembali dokumen kapal, melakukan pelatihan awak kapal perikanan.

Rekomendasi untuk domain sosial: Pendampingan masyarakat dalam pengelolaan SDI melalui program pengelolaan SDI, resolusi konflik (preventif, mitigasikonflik), pendampingan pengetahuan lokal dalam pengelolaan perikanan. Rekomendasi untuk domain ekonomi: penyuluhan tentang pengelolaan aset, pendampingan akan diversifikasi usaha atau alternatif pekerjaan, penyuluhan tentang keuntungan menabung. Rekomendasi untuk domain kelembagaan: Penerapan prinsip-prinsip CCRF dan penerpan aturan berlaku, menyusun kebijakan dan aturan penangkapan dan lainnya serta pemenuhan sarana pengawasan sehingga penindakan pelanggaran dapat menjangkau hingga batas perairan, monitoring kelembagaan pengelolaan perikanan, menetapkan draft RPP Sulawesi Barat menjadi keputusan gubernur dan pelaksanaa RPP Sulawesi Barat.

\section{SIMPULAN}

Hasil analisis dengan pendekatan ekosistem pada pengelolaan perikanan pelagis besar di Kabupaten Mamuju Utara menunjukkan skor indikator tergolong baik pada domain kelembagaan dan domain ekonomi, sedangkan empat indikator lainnya berada pada kategori sedang. Secara umum kondisi pengelolaan perikanan pelagis besar di Kabupaten Mamuju Utara tergolong dalam kategori sedang hingga baik. 
Rekomendasi yang disusun meliputi pengaturan jumlah alat tangkap ikan dan penggunaan rumpon, pengendalian pencemaran perairan dan monitoring kualitas air, peningkatan pengawasan dan penegakan hukum terhadap operasi alat tangkap destruktif, pendampingan pengetahuan lokal dalam pengelolaan perikanan, penyuluhan pengelolaan asset dan pendampingan diversifikasi usaha, penerapan prinsip-prinsip CCRF dan penerapan aturan berlaku.

\section{REFERENSI}

Abdullah, RM, Sugeng, HW, Daniel, RM, \& M. Fedi, AS. (2011). Keberlanjutan perikanan tangkap di Kota Ternate pada dimensi ekologi. Buletin PSP, XIX (1), 113-126.

Abrahamsz, J. \& Ayal Frederik, J. (2015). Penilalian indikator EAFM di Kabupaten Maluku Tenggara. www.eafm-indonesia.net. Diakses 8 November 2017.

Adrianto, L, Habibi A, Fahrudi A, Azizy A, Susanto HA, Kamal MM, Wisudo SH, Wardiatno Y, Raharjo P, Naution Z, \& Yonvitner. (2014). Indikator untuk pengelolaan perikanan dengan pendekatan ekosistem (Ecosystem Approach to Fisheries Management). Modul. Direktorat Sumber Daya Ikan, Kementrian Kelautan dan Perikanan dan National Working Group (NWG) on EAFM, WWF-Indonesia.http://www.eafm-indonesia.net/publikasi/indeks Diakses 12 Agustus 2017.

Alamsyah, R, Musbir \& Amir, F. (2014). Struktur ukuran dan ukuran layah tangkap ikan cakalang (Katsuwonuspelamis) di perairan Teluk Bone. Jurnal. Sains \& Teknologi, 14 (1), 95-100.

Badan Lingkungan Hidup Pemerintah Provinsi Sulawesi Barat. (2015). Penyusunan database dan pemetaan hutan mangrove wilayah pesisir Kabupaten Mamuju Utara. Laporan Akhir. 79 hal: $57 \& 58$.

Bengen, DG. (1999). Pedoman teknis pengenalan dan pengelolaan ekosistem mangrove. Pusat Kajian Sumber Daya Pesisir dan Lautan. Bogor: IPB.

Bengen, DG. (2002). Synopsis ekosistem dan sumber daya alam pesisir. Pusat Kajian Sumber daya Pesisir dan Lautan. Bogor: IPB.

Bessy, Dm \& Aryogagautama, D. (2012). Penilaian performa pengelolaan perikanan menggunakan indikator EAFM (Ecosystem Approach Fisheries Management) kajian perikanan di Kabupaten Alor. FPIK Universitas Kristen Arta Wacana Kupang-WWF Indonesia. 96:13

Brown, BE. (1986). Human induced damage to coral reefs. UNESCO Report in Marine Science 40, Philippines.

Budiarto, A. (2015). Pengelolaan perikanan rajungan dengan pendekatan ekosistem di perairan Laut Jawa (WPPNRI 712). Tesis. Bogor: IPB.

DKP Mamuju Utara. (2016). Data Stastistik Perikanan Tangkap (2011-2016) Mamuju Utara

English, S., C. Wilkinson, \& V. Baker. (1994). Survey manual for tropical marine resources. ASEAN Australia Marine Science Project: Living Coastal Resources. http://www.fishbase.org/Summary/SpeciesSummary.php?ID=107\&AT=cakalang. Diakses 6 Maret 2018.

http://www.fishbase.org/summary/Thunnus-albacares.html. Diakses 6 Maret 2018.

http://www.fishbase.org/summary/93. Bullet tuna (Auxisrochei). Diakses 6 Maret 2018.

Laporan pengawas perikanan Satker Mamuju Utara, 2016. Unit Pelaksana Teknis (UPT) Direktorat Jenderal Pengawasan Sumber Daya Kelautan dan Perikanan.

Latuconsina, H. (2010). Identifikasi alat penangkapan ikan ramah lingkungan di kawasan konservasi laut Pulau Pombo Provinsi Maluku. Jurnal Agrikkan, 3 (2), 23-30. 
Listiani, A, Wijayanto, D \& Jayanto, BB. (2017). Analisis CPUE (catch per unit effort) dan tingkat pemanfaatan sumber daya perikanan lemuru di perairan Selat Bali. Jurnal, Vol. 1. No.01 (2017). UNDIP. http://ejournal2.undip.ac.id. Diakses 10 November 2017.

Mallawa, A, Amir F., \& Zainuddin M. (2014). Keragaan biologi populasiikan cakalang (Katsuwonuspelamis) yang Tertangkap dengan purse seine pada musim timur di perairan Laut Flores. Jurnal IPTEKS PSP, 1(2), 129-145.

McKenzie, LJ. (2003). Draft guidelines for the rapid assessment of seagrass habitat in the wester pacific c. QFS, NFC, Cairns. 43 pp.

McKenzie, LJ, Campbell SJ., \& Roder CA. (2003). Seagrass-watch: manual for mapping \& monitoring seagrass resources by community (citizen) volunteers. $2^{\text {nd }}$ Edition. (QFS, NFC, Cairns) 100 pp.

McKenzie, LJ. (2008). Seagrass educator handbook. Seagrass-Watch, Queensland, Australia.

Minerva A, Firda P. \& Agung S. (2014). Analisi hubungan keberadaan dan kelimpahan lamun dengan kualitas air di Pulau Karimun Jawa, Jepara. Diponegoro Journal of maquares. Management of Aquatic research, 3 (3), 88-94. http:ejournal-s1.undip.ac.id/index.php/maquares. Diakses 03 Mei 2018.

Nugraha E, Bachrulla K., \& Yuniarti. (2012). Potensi lestari dan tingkat pemanfaatan ikan kurisi di perairan Teluk Banten. Jurnal perikanan dan kelautan, 3 (1), 91-98.

Odum, E.P. (1993). Dasar-dasar ekologi. Terjemahan Tjahyono Saminga. Edisi Ketiga. Yogyakarta: Gadjah Mada University Press.

Peraturan Menteri KP No.26/2014.

Setyawan, AD \& K.Winarno, (2006). Pemanfaatan langsung ekosistem mangrove di Jawa Tengah dan penggunaan lahan di sekitarnya; kerusakan dan upaya restorasi. Biodiversitas, Vol. 7 No.3 Juli 2006. Hal. 282-291. Biodiversitas.mipa.uns.ac.id. Diakses 03 Mei 2018.

Sukmara, A., A.J. Siahainenia \& C. Rotinsulu. (2002). Panduan pemantauan terumbu karang berbasis masyarakat dengan metode Manta Tow. Departemen Kelautan dan Perikanan \& Coastal Resource Center University of Rhode Island. 